\title{
短繊維強化複合材中の繊維の可視部分および 隠れた部分の長さの予測理論のシミュレーションによる検討* 鈴寛*1

\author{
Simulational Examination of a Forecast Theory for Visible and \\ Overlapping Parts of Fibers in a Short Fiber Reinforced Composite
}

\author{
Hiroshi SUZUKI*2 \\ *2 Department of Mechanical Engineering, Hachinohe Institute of Technology, \\ 88-1 Obiraki, Myo, Hachinohe-shi, Aomori, 031-8501 Japan
}

\begin{abstract}
In this study, the theory proposed by the author to forecast distributions of length of visible part separated by other fibers and length of overlapping part covered with other fibers which could be observed under the surface of a short fiber reinforced composite was examined. For the examination, packing of fibers in space was computer simulated. The fibers were packed in a cubic space. Random numbers were used to assign position and orientation to the fibers. The computer-simulated short fiber reinforced composite was sectioned at a prescribed thickness. The sectioned simulated sample was observed from the surface, and the distributions of the length of the visible part and the overlapping part were measured. The obtained distributions and the average values of the length of those parts were compared with the distributions and the average values estimated by the theory. The distribution and average value of the length of the visible part estimated by the theory was almost corresponding to the simulational result. In the case that fiber orientation distribution was mostly random in three dimensions, the distribution and average value of the length of the overlapping part estimated by the theory was roughly corresponding to the simulational result.
\end{abstract}

Key Words: Composite Material, Digital Image Processing, Packing Problem, Short Fiber, Visible Part, Overlapping Part

\section{1. 緒言}

短繊維強化複合材は，その成形性の良さもあって, 現在ではさまざまな分野で使用されている，短繊維強 化複合材の力学的特性は, 強化繊維の方向分布や長さ に大きく依存する(1) (3).

短繊維強化複合材内部の繊維の状態を調べるには, 大きく分けて 3 種類のアプローチがある.一つは複合 材表面をきれいに研磨して, 研磨面に現れる繊維断面 像を利用する方法である(4). いわば, 複合材表面で得 られる情報を利用する方法である。一つは, 光学顕微 鏡あるいは共焦点形レーザ顕微鏡を使って, 研磨面下 に観察される繊維の三次元的配置を求める方法であ る(5).いわば, 複合材表面から観察して得られる三次 元情報を利用する方法である。もう一つは, 複合材の 表面を何度も削り，そのたびごとに同一の場所で繊維 断面の輪郭を記録して，その輪郭をつないで複合材中 の繊維の三次元配置を求めたり ${ }^{(6)}$, XMT (X-ray computed microtomography) を使用して, 複合材中の繊 維の三次元配置を求めたりする方法である(7). いわ

* 原稿受付 2007 年 1 月 10 日.

*1 正員, 八戸工業大学工学部(画031-8501 八戸市大字妙字大 開 88-1).

E-mail : suzuki@hi-tech.ac.jp
ば，複合材中の繊維の配置を正確に得る方法である。 複合材表面で得られる情報を利用する方法は，大掛 かりな設備も必要とせず，これを使って繊維方向分布 を容易に求めることができる。しかし，この方法は試 料に垂直な方向に対して繊維中心軸がなす角度が $\theta$ なのか $\theta+\pi$ なのかわからないといった問題( ${ }^{(8)}$ や, 表 面の情報のみを利用するため測定する範囲が大きくな りがちで, 局所的な繊維方向分布の乱れに対応できな いといった問題をもっている. 複合材中の繊維の配置 を正確に得る方法は, 大掛かりな装置を必要としてお り，誰もがそれを利用できるわけではない.

図1の上の図は, コンピュータ上で作成した複合材 中にある繊維の両端が表面から見える角度で示したも のである.すべての繊維の形状は円柱形で, 繊維の直 径および長さは同じである.ガラス纎維を強化材とし て使用して射出成型で短繊維強化複合材を作製する場 合, 複合材中の繊維はうねりをもつが, 本研究ではそ のことは考慮していない. 表面上に一点鎖線を描いた 繊維は, 複合材表面に垂直な方向に対して角度 $\theta$ をな している，中央の図は，これを複合材表面に対して垂 直な方向から観察したものである. 複合材表面から観 察して得られる三次元情報を利用するときには，この 図のような様相が観察できる. 三次元情報を利用する 
方法を使用するに当たっての問題点としては, 図 1 か らわかるように，他の繊維に区切られたいわゆる可視 部分の長さが短いことや, 試料表面から離れるに従っ て他の繊維に覆われる部分の幅が大きくなり，特に覆 われた先端がどこまで伸びているのかわからないこと が挙げられる。

先の論文 ${ }^{(9)}$ で著者は試料表面からの観察による短 繊維強化複合材中の繊維方向分布測定に関する理論的 検討を行った。そのなかで, 測定精度を高めるために は，より繊維の長い範囲での計測が必要であることを 指摘した。したがって，あらかじめ繊維が表面から観 察可能な程度(可視部分の長さの分布)および他の纎維 に覆われている程度(他の纎維に覆われる幅の分布)を 押さえておくことは表面からの観察による䋊維方向分 布測定にとって重要となる。なぜならば, 精度向上に は，他の繊維によって区切られて観察される繊維をつ なぎ合わせて 1 本の繊維とみなす作業が必要となるか らである。

また，他の繊維に覆われた繊維の先端がどこに存在 するかがわかれば, 文献（9)で述べた方法と合わせて 使用することで，繊維の長さ，方向および位置がわか り，このデータを使って有限要素法のメッシュを作成

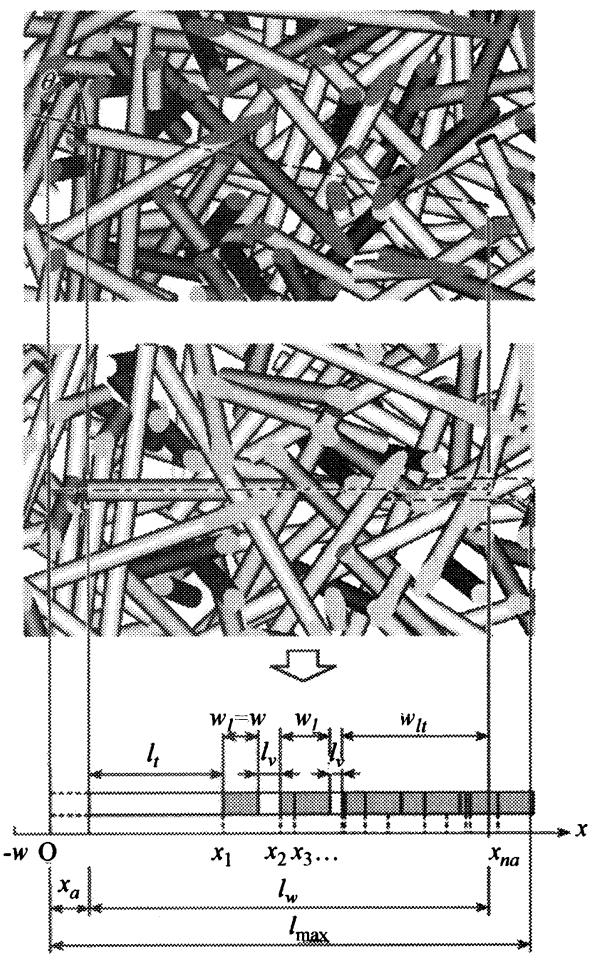

Fig. 1 Simplification of fiber overlapping on the fiber
し, 短繊維強化複合材の強度や剛性を実際の状態に即 して計算することが可能となるかもしれない.

先に, 著者は図 1 の下の図のように(詳細は $2 \cdot 1$ 節 で解説する)他の繊維の重なり部分を幅一定の四角形 で単純化して，他の繊維に区切られたいわゆる可視部 分の長さや(10), 他の繊維に覆われる部分の幅(11) を予 測するための理論式を解析的に導いている．誘導に当 たり四角形の存在確率は試料表面からの深さに比例す ると仮定し, 単純に幾何学的に理論式を導いている. これらは解析的な式なので，プログラミングも容易で あり，計算時間も短くて済むが，これら理論式がどの 程度正確なのかの検証がなされていない。

本研究においては, 先に提案した理論の検証を行っ た. 繊維の直径, 長さおよび方向分布は既知として, 空間中に繊維を数值的に詰め込み, 短繊維強化複合材 をコンピュータ上で作成した。この複合材を切断して 表面から観察し，他の繊維に区切られたいわゆる可視 部分の長さや, 他の繊維に覆われる部分の幅を求め た. 得られた結果と先に提案した理論結果との比較検 討を行い，提案した理論の適用範囲を検証した。

\section{2. 繊維の可視部分および覆われる部分の 長さ予測理論}

$2 \cdot 1$ 繊維の重なりのモデル化 図 1 の中央の図 に示した繊維の重なりを，図１の下の図のように単純 化する，纎維を試料表面に延長し，交差したところに $x$ 軸の原点 $\mathrm{O}$ をとる $x$ 軸の方向は, 試料表面に投影 された繊維の中心軸に平行とする.オリジナルの繊維 の試料表面への投影長さを $l_{w}$, 重なりを考える範囲の 長さを $l_{\max }$ とする。この長さ $l_{\max }$ は, オリジナルの 繊維を試料表面抢よび裏面に延長し，これを試料表面 に投影した長さよりも長くなければならない。さらに オリジナルの繊維の表面に近いほうの端を試料表面に 投影したときの $x$ 座標を $x_{a}$ とする. 図 1 の中央の図 を見ると，シミュレーションにおいては，注目する繊 維に他の繊維がさまざまな角度で重なり,さらに, 繊 維の端が重なっている場合も多数見受けられるが, 本 研究では，注目する繊維に他の 1 本の繊維が重なった 部分を一定幅 $w$ の四角形で単純化する．幅 $w$ は繊維 の直径 $d$, または無限に長い繊維がランダムに重なっ たときの重なり部分の幅の平均值 $\pi d / 2$ のいずれかと する.繊維両端の間で繊維が重なった部分の幅を $w_{l}$, 繊維端まで重なる部分の幅を $w_{l t}$ とする．繊維の重な りを単純化した四角形の位置を四角形の左端の $x$ 座 標で表す、繊維端と一つの四角形に挟まれてできる可 視部分の長さを $l_{t}$, 二つの四角形に挟まれてできる可 
視部分の長さを $l_{v}$ とする.

本研究では重なる繊維の位置の確率密度関数 $f_{d}(x$,

$\theta)$ は $x=-w \sim x=l_{\max }$ の範囲内で

$$
f_{d}(x, \theta)=a_{d} x+b_{d}
$$

で表されるものとする。ここで

$$
b_{d}=\frac{a_{d}\left(-l_{\max }+w\right)}{2}+\frac{1}{l_{\max }+w}
$$

式 (1) は重なる繊維の数が試料両面からの距離に比例 して増加することを示している.

繊維の重なりを単純化した四角形は $x=-w \sim x=$ $l_{\max }$ の範囲に $n_{a}$ 個存在するものとする. 四角形の個 数 $n_{a}$ および式(1)の係数 $a_{d}$ の決定については文献 (10)によった. 他の 1 本の繊維が重なった部分を幅 $d$ の四角形で近似したときの四角形の個数のほうが, 幅 $\pi d / 2$ の四角形で近似したときの四角形の個数より多 くなった.

$2 \cdot 2$ 可視部分の長さ分布 本節では, 図 1 に示 した繊維端と一つの四角形に挟まれてできる可視部分 の長さ $l_{t}$ をさらに 2 種類に分類する. 繊維上端ある いは表面に切られてできる繊維端と一つの四角形に挟 まれてできる可視部分の長さを $l_{t 1}$ とし, 繊維下端あ るいは裏面に切られてできる繊維端と一つの四角形に 挟まれてできる可視部分の長さを $l_{t 2}$ とする.

繊維上端あるいは表面に切られてできる繊維端と一 つの四角形に挟まれてできる可視部分の長さ $l_{t 1}$ が $x_{d} \sim x_{d}+\mathrm{d} x_{d}$ の範囲にある確率 $f_{t 1} \mathrm{~d} x_{d}$ は文献 $(10)$ よ $\eta$

$$
f_{t 1} \mathrm{~d} x_{d}=\left\{\begin{array}{l}
n_{a}\left[\frac{a_{d}\left(2 x_{d}+2 x_{a}-l_{\max }+w\right)}{2}+\frac{1}{l_{\max }+w}\right]\left\{-\frac{a_{d}\left[x_{d}^{2}+\left(2 x_{a}-l_{\max }+w\right) x_{d}+\left(2 x_{a}-l_{\max }\right) w\right]}{2}\right. \\
\left.\quad+\frac{l_{\max }-x_{d}}{l_{\max }+w}\right\}^{n_{a}-1} \mathrm{~d} x_{d} \quad\left(0 \leq x_{d}<l_{w}\right) \\
0 \quad\left(x_{d}<0 \text { or } x_{d} \geq l_{w}\right)
\end{array}\right.
$$

緘維下端あるいは裏面に切られてできる繊維端と一つの四角形に挟まれてできる可視部分の長さ $l_{t 2}$ が $x_{d} \sim x_{d}$ $+\mathrm{d} x_{d}$ の範囲にある確率 $f_{t 2} \mathrm{~d} x_{d}$ は

$$
f_{t 2} \mathrm{~d} x_{d}=\left\{\begin{array}{l}
n_{a}\left[\frac{a_{d}\left(-2 x_{d}+2 x_{a}+2 l_{w}-l_{\max }-w\right)}{2}+\frac{1}{l_{\max }+w}\right]\left\{-\frac{a_{d}\left[-x_{d}^{2}+\left(2 x_{a}+2 l_{w}-l_{\max }-w\right) x_{d}\right]}{2}\right. \\
\left.\quad-\frac{a_{d}\left(2 x_{a}+l_{w}-l_{\max }\right) w}{2}+\frac{l_{\max }-x_{d}}{l_{\max }+w}\right\}^{n_{a}-1} \mathrm{~d} x_{d} \quad\left(0 \leq x_{d}<l_{w}\right) \\
0 \quad\left(x_{d}<0 \text { or } x_{d} \geq l_{w}\right)
\end{array}\right.
$$

二つの四角形に挟まれてできる可視部分の長さ $l_{v}$ が $x_{d} \sim x_{d}+\mathrm{d} x_{d}$.の範囲にある本数 $f_{v} \mathrm{~d} x_{d}$ は

$$
f_{v} \mathrm{~d} x_{d}=\left\{\begin{array}{l}
n_{a}\left(n_{a}-1\right) \int_{x_{1}=x_{a}-w}^{x_{1}=x_{d}+x_{a}+l_{w}-w} f_{12} P_{12} \mathrm{~d} x_{1} \mathrm{~d} x_{d} \quad\left(0 \leq x_{d}<l_{w}\right) \\
0 \quad\left(x_{d}<0 \text { or } x_{d} \geq l_{w}\right)
\end{array}\right.
$$

ここで, $f_{12} \mathrm{~d} x_{1}$ および $P_{12}$ はそれぞれ

$$
\begin{aligned}
& f_{12} \mathrm{~d} x_{1}=\left[\frac{a_{d}\left(2 x_{1}-l_{\max }+w\right)}{2}+\frac{1}{l_{\max }+w}\right]\left[\frac{a_{d}\left(2 x_{1}+2 x_{d}-l_{\max }+3 w\right)}{2}+\frac{1}{l_{\max }+w}\right] \mathrm{d} x_{1} \\
& P_{12}=\left\{1-\left(x_{d}+w\right)\left[\frac{a_{d}\left(2 x_{1}+x_{d}-l_{\max }+2 w\right)}{2}+\frac{1}{l_{\max }+w}\right]\right\}^{n_{a-2}} \cdots \ldots \ldots \ldots \ldots \ldots \ldots \ldots \ldots \ldots \ldots \ldots \ldots \ldots \ldots \ldots \ldots \ldots \ldots \ldots \ldots \ldots \ldots
\end{aligned}
$$

式 $(3)$ （５）は1本の繊維における可視部分の長さ分布を表し，これに角度，長さ，位置のそれぞれの微小範囲 における纎維本数を掛けて積分すれば, 観察される可視部分の長さ分布を求めることができる(10).

$2 \cdot 31$ 本の繊維上に重なる長方形の幅の分布 複数個の四角形からなる長方形の幅の分布を解析的に求めた 結果を紹介する，著者は文献(11)でこの幅の分布を誘導しているが，スペースの関係で，完全な形では示していな い.ここでは, 誘導方法を省略して, 結果のみを示す.

図 1 のよう， $n_{a}$ 個の四角形が $x=-w \sim x=l_{\max }$ の範囲にあるとき，この中のいくつかの四角形が重なって細 長い長方形を形成する， $k$ 個の四角形が重なって位置が $x_{l}$, 幅 $w_{l}$ の長方形が形成されたとき, この長方形に残り の $n_{a}-k$ 個の四角形の中の一つの四角形も重ならない確率 $P_{u}\left(x_{l}, w_{l}, n_{a}-k, \theta\right)$ は

$$
P_{u}\left(x_{l}, w_{l}, n_{a}-k, \theta\right)=\left[-\frac{a_{d}}{2} w_{l}^{2}-\left(a_{d} x_{l}+a_{d} w+b_{d}\right) w_{l}+\frac{a_{d}}{2} w^{2}-b_{d} w+1\right]^{n_{a}-k}
$$


次に，四角形が他の四角形に重ならず単独に存在す る確率を示す. 繊維上で幅 $w$ の四角形が $x=x_{\imath} \sim x=$ $x_{l}+\mathrm{d} x_{l}$ の範囲にあり, この四角形に他の四角形が重 ならない確率 $g_{c 1}\left(x_{l}, \theta\right) \mathrm{d} x_{l}$ は

$$
g_{c 1}\left(x_{l}, \theta\right) \mathrm{d} x_{l}=n_{a} f_{d}\left(x_{l}, \theta\right) P_{u}\left(x_{l}, w, n_{a}-1, \theta\right) \mathrm{d} x_{l}
$$

2 個以上の四角形が重なってできる長方形の幅の分 布を示そう。 $n_{a}$ 個ある四角形の中の 2 個以上が重な ってできる長方形の位置が $x=x_{l} \sim x=x_{l}+\mathrm{d} x_{l}$ の範 囲にあり，その幅が $w_{l} \sim w_{l}+\mathrm{d} w_{l}$ の範囲にあり，他の 四角形がこの長方形と重ならない確率 $f_{c}\left(x_{l}, w_{l}\right.$, $\theta) \mathrm{d} x_{l} \mathrm{~d} w_{l}$ は次式で表すことができる.

$$
\begin{aligned}
& f_{c}\left(x_{l}, w_{l}, \theta\right) \mathrm{d} x_{l} \mathrm{~d} w_{l}=\sum_{k=n_{r}}^{n_{a}} P_{k}^{n_{a}} f_{c k}\left(x_{l}, w_{l}, \theta\right) \\
& \quad \times P_{u}\left(x_{l}, w, n_{a}-k, \theta\right) \mathrm{d} x_{l} \mathrm{~d} w_{l} \quad\left(w<w_{l} \leq n_{a} w\right)
\end{aligned}
$$

ここで

$$
n_{r}=\operatorname{int}\left(w_{l} / w\right)+1
$$

であり, $P_{k}^{n_{a}}$ は順列の数, $f_{c k}\left(x_{l}, w_{l}, \theta\right) \mathrm{d} x_{l} \mathrm{~d} w_{l}$ は, $n_{a}$ 個ある四角形の中の $k$ 個が重なってできる長方形の 位置が $x=x_{l} \sim x=x_{l}+\mathrm{d} x_{l}$ の範囲にあり，その幅が $w_{l} \sim w_{l}+\mathrm{d} w_{l}$ の範囲にある確率である. 確率 $f_{c k}\left(x_{l}\right.$, $\left.w_{l}, \theta\right) \mathrm{d} x_{l} \mathrm{~d} w_{l}$ は長方形の幅 $w_{l}$ の $2 k-3$ 次式で与えら れ, 長方形の幅 $w_{l}$ が $n_{k} w \leq w_{l} \leq\left(n_{k}+1\right) w\left(n_{k}=1,2\right.$, $\cdots, k-1)$ の範囲にあるとき

$$
f_{c k}\left(x_{l}, w_{l}, \theta\right) \mathrm{d} x_{l} \mathrm{~d} w_{l}=\sum_{i=0}^{2 k-3}\left(C_{k, l_{1}+i} w_{l}^{i}\right) \mathrm{d} x_{l} \mathrm{~d} w_{l}
$$

で表される。ここで係数 $C_{k, l_{1}+i}$ の下添字 $k$ は, 長方 形が $k$ 個の四角形により構成されていることを表し， $l_{1}$ は

$$
l_{1}=2(k-2)\left(n_{k}-1\right)
$$

である.

$k=2$ の場合, 確率 $f_{c 2}^{*}\left(x_{l}, w_{l}, \theta\right) \mathrm{d} x_{l} \mathrm{~d} w_{l}$ は次式で与 えられる。

$f_{c 2}\left(x_{l}, w_{l}, \theta\right) \mathrm{d} x_{l} \mathrm{~d} w_{l}=\left(C_{2,0}+C_{2,1} w_{l}\right) \mathrm{d} x_{l} \mathrm{~d} w_{l}$

$$
\text { ここで }
$$

$$
\begin{aligned}
& C_{2,0}=A\left(a_{d} x_{l}+b_{d}\right) \\
& C_{2,1}=a_{d}\left(a_{d} x_{l}+b_{d}\right)
\end{aligned}
$$

であり,さらに

$$
A=a_{d}\left(x_{l}-w\right)+b_{d}
$$

である.

$k>2$ の場合, 長方形の幅 $w_{l}$ が $w<w_{l} \leq 2 w$ の範囲 では, $n_{k}=1$ で $l_{1}=0$ となることを考慮して, 確率 $f_{c k}\left(x_{l}, w_{l}, \theta\right) \mathrm{d} x_{l} \mathrm{~d} w_{l}$ の係数 $C_{k, i}$ は次式により求める
ことができる。

$$
\begin{aligned}
& C_{k, 0}=-A \sum_{j=0}^{2 k-5} \frac{C_{k-1, j}}{j+1} w^{j+1} \\
& C_{k, 1}=A C_{k-1,0}-a_{d} \sum_{j=0}^{2 k-5} \frac{C_{k-1, j}}{j+1} w^{j+1} \\
& C_{k, i}=\frac{A C_{k-1, i-1}}{i}+\frac{a_{d} C_{k-1, i-2}}{i-1} \\
& (i=2,3, \cdots, 2 k-4) \\
& C_{k, 2 k-3}=\frac{a_{d} C_{k-1,2 k-5}}{2 k-4}
\end{aligned}
$$

長方形の幅 $w_{\iota}$ が $2 w<w_{l} \leq(k-1) w$ の範囲では, 確率 $f_{c k}\left(x_{l}, w_{l}, \theta\right) \mathrm{d} x_{l} \mathrm{~d} w_{l}$ の係数 $C_{k, l_{1}+i}$ は次式により 求めることができる.

$$
\begin{aligned}
& C_{k, l_{1}}=A B \cdots \cdots \cdots \cdots \cdots \cdots \cdots \cdots \cdots \cdots \cdots \cdots \cdots \cdots \cdots \cdots \cdots \cdots \cdots \cdots \cdots \cdots \cdots \cdots \cdots \cdots \cdots \cdots \cdots \\
& C_{k, l_{1}+1}=a_{d} B+A D_{1} \cdots \cdots \cdots \cdots \cdots \cdots \cdots \\
& C_{k, l_{1}+i}=a_{d} D_{i-1}+A D_{i} \quad(i=2,3, \cdots, 2 k-4)
\end{aligned}
$$

$C_{k, l_{1}+2 k-3}=a_{d} D_{2 k-4}$

であり,さらに

$$
\begin{aligned}
B & =\sum_{j=0}^{2 k-5} \frac{1}{j+1}\left[\left(C_{k-1, l_{2}+j}-C_{k-1, l_{3}+j}\right)\left(n_{k} w\right)^{j+1}\right. \\
& \left.-(-1)^{j+1} C_{k-1, l_{3}+j} w^{j+1}\right] \cdots \cdots \cdots \cdots \cdots \cdots \cdots \cdots \\
D_{i} & =\frac{C_{k-1, l_{3}+i-1}}{i} \\
& -\sum_{j=i}^{2 k-4} \frac{(-1)^{j-i} C_{i}^{j} C_{k-1, l_{2}+i-1} w^{j-i}}{j} \cdots \cdots \cdots
\end{aligned}
$$

ここで

$$
\begin{aligned}
& l_{2}=2(k-2)\left(n_{k}-2\right) \\
& l_{3}=2(k-2)\left(n_{k}-3\right)
\end{aligned}
$$

であり, $C_{i}^{j}$ は組合せの数である.

長方形の幅 $w_{l}$ が $(k-1) w<w_{l} \leq k w$ の範囲では, 確率 $f_{c k}\left(x_{l}, w_{l}, \theta\right) \mathrm{d} x_{l} \mathrm{~d} w_{l}$ の係数 $C_{k, l_{1}+i}$ は次式により 求めることができる.

$$
\begin{aligned}
& C_{k, l_{1}}=A E \text {. } \\
& C_{k, l_{1}+1}=a_{d} E-A F_{1} \\
& C_{k, l_{1}+i}=-a_{d} F_{i-1}-A F_{i} \quad(i=2,3, \cdots, 2 k-4)
\end{aligned}
$$

$$
C_{k, l_{1}+2 k-3}=a_{d} F_{2 k-4}
$$

ここで

$$
E=\sum_{j=0}^{2 k-5} \frac{\left\{[(k-1) w]^{j+1}-(-w)^{j+1}\right\} C_{k-1, l_{2}+j}}{j+1}
$$

$$
F_{i}=\sum_{j=i}^{2 k-4} \frac{(-1)^{j-i} C_{i}^{j} C_{k-1, l_{2}+i-1} w^{j-i}}{j}
$$

$2 \cdot 4$ 他の繊維によって覆われる幅の予測法 式 (9)㧍よび式(10)により，四角形あるいは長方形で近 似した他の繊維が 1 本の繊維に重なる部分の幅の分布 を求めることができる.これを使って, 試料表面から 
観察して得られる瀻維の先端部分が他の繊維によって覆われる幅 $w_{l t}$ の分布および繊維端の間で他の繊維に覆われ る幅 $w_{\iota}$ の分布の求め方を考光よう.

試料表面に近い端の部分が覆われる幅の確率と遠い端の部分が覆われる幅の確率を別々に評価して加え合わせる

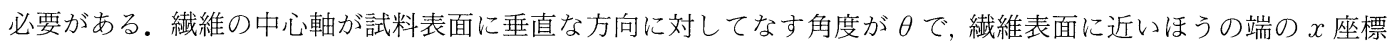
が $x_{a}$ であるとき, 試料表面に近いほうの端付近が他の瀻維に覆われる幅が $w_{l t} \sim w_{l t}+\mathrm{d} w_{l t}$ の範囲にある確率 $f_{l t u}\left(w_{l t}, x_{a}, \theta\right) \mathrm{d} w_{l t}$ は次式で求めることができる.

$$
f_{l t u}\left(w_{l t}, x_{a}, \theta\right) \mathrm{d} w_{l t}=\left\{\begin{array}{l}
g_{c 1}\left(w_{l t}+x_{a}-w, \theta\right) \mathrm{d} w_{l t}+\int_{w_{l}=w}^{w_{l}=-x_{l}+x_{a}+l_{w}} f_{c}\left(w_{l t}+x_{a}-w, w_{l}, \theta\right) \mathrm{d} w_{l} \mathrm{~d} w_{l t} \\
\left(0<w_{l t}<w\right) \\
\int_{w_{l}=w_{l t}}^{w_{l=-x_{l}+x_{a}+l_{w}}} f_{c}\left(w_{l t}+x_{a}-w, w_{l}, \theta\right) \mathrm{d} w_{l} \mathrm{~d} w_{l t} \quad\left(w \leq w_{l t}\right)
\end{array}\right.
$$

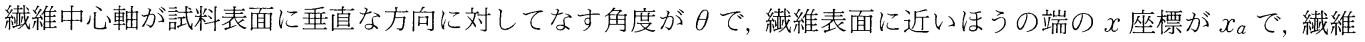
の試料表面への投影長さが $l_{w}$ のを, 試料表面から遠いほうの端付近が他の繊維に覆われる幅が $w_{l t} \sim w_{l t}+\mathrm{d} w_{l t}$ の範囲にある確率 $f_{l t l}\left(w_{l t}, x_{a}, \theta\right) \mathrm{d} w_{l t}$ は次式で求めることができる.

$$
f_{l t l}\left(w_{l t}, x_{a}, l_{w}, \theta\right) \mathrm{d} w_{l t}=\left\{\begin{array}{l}
g_{c 1}\left(-w_{l t}+x_{a}+l_{w}, \theta\right) \mathrm{d} w_{l t}+\int_{w_{l}=w}^{w_{l}=n_{a} w} f_{c}\left(-w_{l t}+x_{a}+l_{w}, w_{l}, \theta\right) \mathrm{d} w_{l} \mathrm{~d} w_{l t} \\
\left(0<w_{l t}<w\right) \\
\int_{w_{l}=w_{l t}}^{w_{l}=n_{a} w} f_{c}\left(-w_{l t}+x_{a}+l_{w}, w_{l}, \theta\right) \mathrm{d} w_{l} \mathrm{~d} w_{l t} \quad\left(w \leq w_{l t}\right)
\end{array}\right.
$$

繊維の表面に近いほうの端の $x$ 座標 $x_{a}$, 試料表面 への投影長さ $l_{w}$ および角度 $\theta$ をもつ繊維が複合材中 に存在する確率を，文献(10)を参考にして求める。こ れを式(36)㧍よび式(37)に掛け合わせ合計することに より, 複合材表面から観察される瀻維の先端部分が他 の㵶維に覆われる幅 $w_{l t}$ の分布を推定する.

複合材表面から観察される繊維の端の間が他の繊維 に覆われるとき，重なり部分を近似した長方形は二つ の繊維端の間にある。この条件のもと, 式 $(9)$ および 式(10)に, 瀻維の表面に近いほうの端の $x$ 座標 $x_{a}$, 試料表面への投影長さ $l_{w}$ および角度 $\theta$ をもつ瀻維が 複合材中に存在する確率を掛けて合計し, 纎維端の間 で他の纎維に覆われる幅 $w$ の分布を求める.

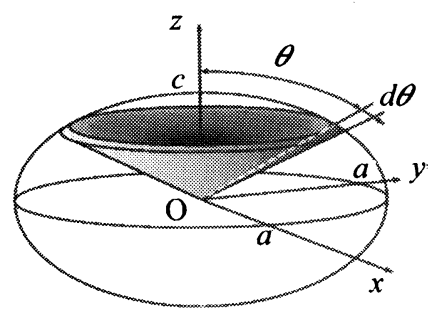

Fig. 2 Schematic diagram for definition of fiber orientation distribution

\section{3. 繊維の詰め込み問題}

$3 \cdot 1$ 詰め込み手法の概要 2 章に示した理論に より予測される繊維の可視部分および他の繊維に覆わ れる部分の長さ分布の検証を行うために, 直径 $d$, 長 さ $l_{f}$ の繊維を模した円柱を, 立方体状の空間中に詰 め込む問題を考える. 繊維等の物体をコンピュータ上 で空間中に詰め込むには，文献(12)のように，さまざ まな手法がある、本研究で採用した手法の詳細につい ては文献 $(9)$ に述べられている。ここでは, その概略 を説明する。

乱数で候補者である繊維の位置および方向を決め, この繊維を立方体状の空間中に配置し，すでに空間中 に配置してある他の繊維と重なる場合にはこれを破充 して, 次の瀻維を配置する.他の繊維と重なりがなけ れば，この繊維を複合材中の繊維として採用する。こ の操作を所定の繊維体積含有率になるまで繰返す。

立方体の境界では繰返しの条件を導入する。すなわ ち，境界から外側に伸びる䋊維は，この境界と反対側 の境界から空間内に入り込むものとする。

$3 \cdot 2$ 繊維方向分布 本研究では, 複合材中の繊 維方向分布を試料表面に対して垂直な方向に回転軸を もつ回転だ円体の内部の体積で表す．図 2 を使って回 転だ円体で表現される繊維方向分布を説明する．図 2 では回転軸は $z$ 軸となっている。回転だ円体の中心 を座標軸の原点におき，回転だ円体が $x$ 軸および $y$ 
軸と交わる座標を $a, z$ 軸と交わる座標を $c$ とする。 回転だ円体の中心を通り, $z$ 軸に対して角度 $\theta$ をなす 曲面と角度 $\theta+\mathrm{d} \theta$ をなす曲面とだ円体の表面で囲ま れる部分の体積で, 角度が $\theta \sim \theta+\mathrm{d} \theta$ の間にある繊維 の割合 $f_{\theta}(\theta) \mathrm{d} \theta$ を表す。本研究では方向分布を表す パラメータとして回転だ円体の主軸の長さの比 $c / a$ を 採用する. 方向分布を表すパラメー夕 $c / a$ が 1 を境と して, パラメータ $c / a$ が 1 より小さいときには試料表 面に対して平行に近い繊維が多くなり，パラメー夕 $c / a$ が 1 より大きいときには試料表面に対して垂直に 近い纎維が多くなる.

$3 \cdot 3$ 繊維の詰め込みの例 繊維長さ $l_{f}$ が繊維直 径 $d$ の 20 倍すなわち $20 d$ の繊維を, 一辺の長さが $3\left(l_{f}+d / 2\right)$ の立方体中に䋊維体積含有率 $v_{f}$ が 0.15 と なるように詰め込んだ.このコンピュータ上で作成し た複合材を, 厚さ $t$ が繊維直径 $d$ の 10 倍の厚板状に 切断した. 結果の例を図 3 に示す. 厚さ方向を $z$ 軸 の方向としている. 図は $3 \cdot 2$ 節で定義した繊維方向を 表すパラメータ $c / a$ が 1.0 で三次元ランダムのときの 結果である. パラメータ $c / a$ が 1 未満のとき, 表面に 平行に近い繊維が多く, 1 を超えると, 表面に垂直に 近い繊維が多い. 先に示した図 1 は図 3 に示した複合 材を表面から観察した図である.シミュレーションで

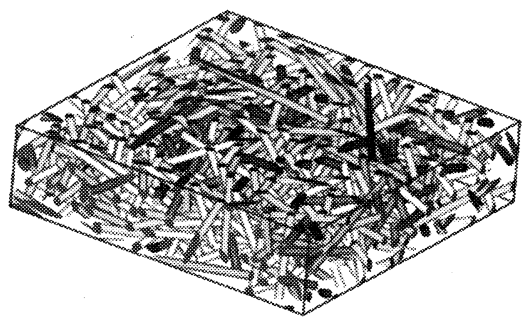

Fig. 3 Circumstances of the packed fibers

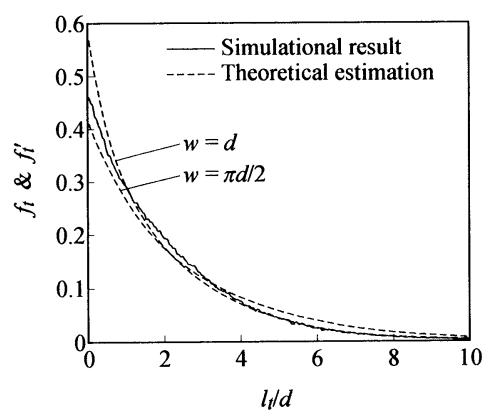

Fig. 4 Probabilistic density functions $f_{t}$ and $f_{t}^{\prime}$ of visible length $l_{t}$ on a fiber end estimated by the simple theory and the computer-simulation
得られた複合材を表面から観察して繊維端と他の繊維 に挟まれてできる可視部分の長さ $l_{t}$, 他の 2 本の繊維 に挟まれてできる可視部分の長さ $l_{v}$, 先端部分が他の 繊維に覆われる幅 $w_{l t}$ および繊維端の間が他の繊維に 覆われる幅 $w \iota の$ 分布を求めた。

\section{4. 計算結果および考察}

$4 \cdot 1$ 可視部分の長さの分布および平均值 $\quad 2 \cdot 2$ 節で述べた方法により, 繊維端と他の繊維に挟まれて できる可視部分の長さ $l_{t}$ および 2 本の他の繊維に挟 まれてできる可視部分の長さ $l_{v}$ の分布を計算した。 繊維長さ $l_{f}$ を繊維直径 $d$ の 20 倍, すなわち $20 d$, 試 料の厚さ $t$ を繊維直径の 10 倍, すなわち $10 d$, 繊維体 積含有率 $v_{f}$ を 0.15 , 繊維方向分布を表すパラメータ $c / a$ を $0.2,0.5,1.0,2.0$ および 4.0 とした. 繊維の 重なり部分を近似する四角形の幅 $w$ を繊維直径 $d$ と 同一の場合と, 幅 $w$ の繊維が二次元的にランダムに 重なったときの幅の平均值 $\pi d / 2$ の場合の 2 種類とし た.

可視部分の長さ分布の計算例として, 繊維方向分布 を表すパラメータ $c / a$ が 1.0 (三次元ランダム)のとき の繊維端と他の繊維に挟まれてできる可視部分の長さ $l_{t}$ の理論により得られる確率密度関数 $f_{t}$ およびシミ ュレーションにより得られる確率密度関数 $f_{t}^{\prime}$ を図 4 に, 2 本の他の繊維に挟まれてできる可視部分の長さ $l_{v}$ の理論により得られる確率密度関数 $f_{v}$ およびシミ ュレーションにより得られる確率密度関数 $f_{v}^{\prime}$ を図 5 に示す.

図 4 に注目すると, 繊維端と他の繊維に挟まれてで きる可視部分の長さ $l_{t}$ の確率密度関数は理論結果も シミュレーション結果も, $l_{t}=0$ から単調に減少し, $l_{t}$ $=10 d$ でほぼ零になることがわかる.シミュレーショ

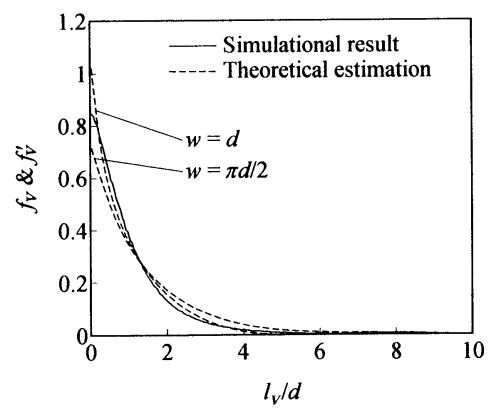

Fig. 5 Probabilistic density functions $f_{v}$ and $f_{v}^{\prime}$ of visible length $l_{v}$ separated by two fibers estimated by the simple theory and the computer-simulation 
ンによって得られる繊維端と他の繊維に挟まれてでき る可視部分の長さの確率密度関数は, 近似する四角形 の幅 $w$ をとしたときに得られる繊維端と他の瀻維 に挟まれてできる可視部分の長さの確率密度関数によ り近い。

図 5 に注目すると，2 本の他の繊維に挟まれてでき る可視部分の長さ $l_{v}$ の確率密度関数は理論結果もシ ミュレーション結果も, $l_{v}=0$ から単調に減少し, $l_{v}=$ $5 d$ でほぼ零になることがわかる.シミュレーション によって得られる 2 本の他の繊維に挟まれてできる可 視部分の長さの確率密度関数は, 近似する四角形の幅 $w$ を繊維直径 $d$ と同一として予測した結果により近 w.

理論により得られる繊維端と他の繊維に挟まれてで

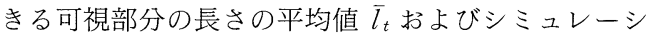
ヨンにより得られる繊維端と他の繊維に挟まれてでき る可視部分の長さの平均値 $\bar{l}_{t}^{\prime}$ を求め図 6 に示す. 瀻 維方向分布を表すパラメータ $c / a$ が増加するにつれて 平均值 $\bar{l}_{t}$ および $\bar{l}_{t}^{\prime}$ は減少する. 試料表面に対して繊 維が垂直に近くなり, 試料表面への繊維の投影長さが 短くなるにつれて, 繊維端と他の繊維に挟まれてでき る可視部分の長さの平均值は減少する. シミュレーシ ヨンにより得られる繊維端と他の繊維に挟まれてでき る可視部分の長さの平均値は, 近似する四角形の幅 $w$ を繊維直径 $d$ と同一として予測した平均值にほぼ一 致する。

理論により得られる他の 2 本の繊維に挟まれてでき る可視部分の長さの平均值 $\bar{l}_{v}$ およびシミュレーショ ンにより得られる他の 2 本の繊維に挟まれてできる可 視部分の長さの平均值 $\bar{l}_{v}^{\prime}$ を求め図 7 に示す. 理論に より得られる他の 2 本の繊維に挟まれてできる可視部 分の長さの平均值は, 繊維方向分布を表すパラメータ

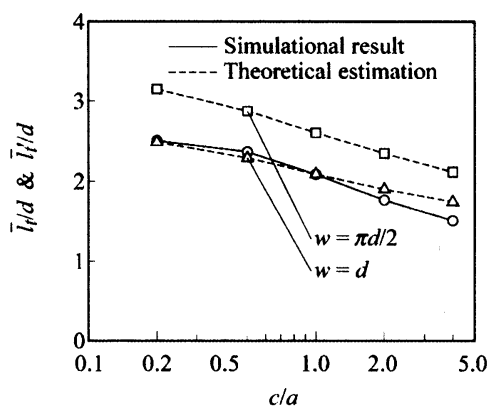

Fig. 6 Difference between average values of visible length $\bar{l}_{t}$ and $\bar{l}_{t}^{\prime}$ on a fiber end estimated by the simple theory and the computer-simulation in several fiber orientation distributions $c / a$ が 0.2 から 1.0 の範囲では, 近似する四角形の幅 $w$ を繊維直径 $d$ としたときほほ $d$, 近似する四角形 の幅 $w$ を $\pi d / 2$ としたときほぼ $1.5 d$ 一定で, $c / a$ が 1.0 を超えると増加する. これに対して, シミュレー ションにより得られる他の 2 本の繊維に挟まれてでき る可視部分の長さの平均值は, 繊維方向分布を表すパ ラメータ $c / a$ が 0.2 のと, すなわち, 試料中の繊維 が試料表面に平行に近く, 繊維が二次元的に配置され たときには, 近似する四角形の幅 $w$ を $\pi d / 2$ として予 測した可視部分の長さの平均值にほぼ等しく, 繊維方 向分布を表すパラメータ $c / a$ が 0.5 を超えると, 近似 する四角形の幅 $w$ を $d$ として予測した可視部分の長 さの平均值にほぼ等しい.

さらなる詳細な検討が必要であるが, 著者は可視部 分の長さの平均值は他の繊維が重なる数に大きく依存 すると考えている. 本研究では, 繊維方向が試料表面 に平行な面内でランダムとして計算を行っている. 繊 維が無限に長ければ, 近似する四角形の幅 $w$ を $\pi d / 2$ とおいて求めた本数だけ注目する繊維に他の繊維が重 なる．緘維方向分布を表すパラメー夕 $c / a$ が 0.2 のと き, 近似する四角形の幅 $w$ を $\pi d / 2$ として予測した他 の 2 本の繊維に挟まれてできる可視部分の長さの平均 值が, シミュレーションにより得られる可視部分の長 さの平均値に近いのはこのためであろう.しかし, 多 くの場合繊維長さが有限で端が存在するために, 試料 表面への投影長さが長くなり, 他の繊維が重なる本数 が多くなる.このため, 四角形の幅 $w$ を $d$ として予 測した可視部分の長さの平均值はシミュレーション結 果に近い值になったと考えられる。

\section{$4 \cdot 2$ 他の繊維に覆われる幅の分布および平均值}

$2 \cdot 3$ 節で述べた方法により繊維の先端部分が他の繊維

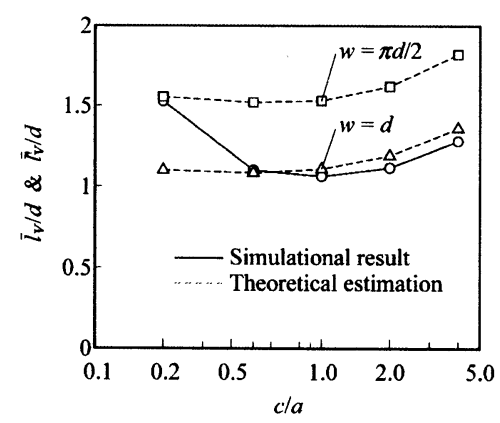

Fig. 7 Difference between average values of visible length $\bar{l}_{v}$ and $\bar{l}_{v}^{\prime}$ separated by two fibers estimated by the simple theory and the computersimulation in several fiber orientation distributions 
に覆われる幅 $w_{l t}$ の分布および繊維端の間が他の瀻維 に覆われる幅 $w_{l}$ の分布を計算した. 瀻維長さ $l_{f}$, 試 料の厚さ $t$, 繊維体積含有率 $v_{f}$ および繊維方向分布 を表すパラメータ c/a の值はそれぞれ $4 \cdot 1$ 節の計算に 使用した值と同一とした。瀻維の重なり部分を近似す る四角形の幅 $w$ を $d$ の場合と, $\pi d / 2$ の場合の 2 種類 とした。

他の繊維に覆われる幅の分布の計算例として, 繊維 方向分布を表すパラメータ $c / a$ が 1.0 (三次元ランダ ム)のときの繊維の先端部分が他の繊維に覆われる幅 $w_{l t}$ の理論により得られる確率密度関数 $f_{w t}$ およびシ ミュレーションにより得られる確率密度関数 $f_{w t}^{\prime}$ を図 8 に, 繊維端の間が他の繊維に覆われる幅 $w_{l}$ の理論 により得られる累積確率 $F_{w}$ およびシミュレーション により得られる累積確率 $F_{w}^{\prime}$ を図 9 に示す.

図 8 に注目すると, 理論により求めた繊維の先端部 分が他の繊維に覆われる幅の確率密度関数 $f_{w t}$ は, $w_{l t}=0$ から重なり部分を近似した四角形の幅まで 徐々に減少し，そこを過ぎると急激に減少する。これ

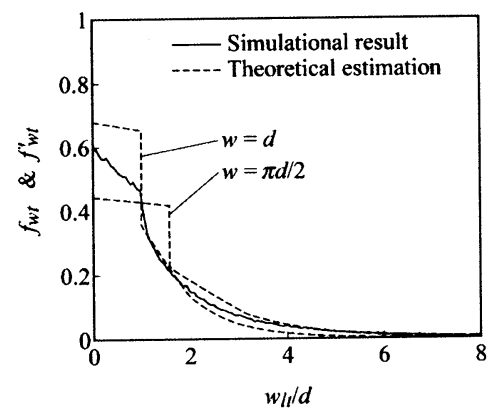

Fig. 8 Probabilistic density functions $f_{w t}$ and $f_{w t}^{\prime}$ of length of the overlapping part on a fiber end $w_{l t}$ estimated by the simple theory and the computer-simulation

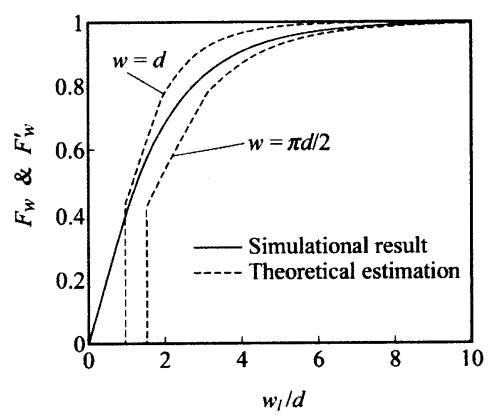

Fig. 9 Cumulative probabilities $F_{w}$ and $F_{w}^{\prime}$ of length of the overlapping part between fiber tips $w_{l}$ estimated by the simple theory and the computersimulation
に対して，シミュレーションにより求めた繊維の先端 部分が他の繊維に覆われる幅 $w_{l t}$ の確率密度関数 $f_{w t}^{\prime}$ は, $w_{l t}$ が繊維直径 $d$ の位置で折れ曲がることは, 重 なり部分を繊維直径 $d$ で近似したときの理論結果と 同様であるが，それまでの減少率がシミュレーション により求めた確率密度関数のほうが大きい. 本研究で 用いた理論では，他の繊維が重なる幅を一定値として おり，これも原因となって減少率の差が生じている.

図 9 に注目すると, 理論により求めた瀻維端の間が 他の繊維に覆われる幅 $w l$ の累積確率 $F_{w}$ は重なり部 分を近似した四角形の幅のところで約 0.4 まで立上が り，その後は単調に増加する。これに対して, シミュ レーションにより求めた累積確率 $F_{w}^{\prime}$ は $w_{l}=0$ から単 調に増加し，wlが $10 d$ になるとほほ 1 になる．図 9 に示したような繊維方向分布が三次元ランダムの場合 には, 理論結果の立上がり部分を除いて, シミュレー ションにより求めた累積確率 $F_{w}^{\prime}$ の曲線は, 繊維の重 なり部分を近似する四角形の幅 $w$ を $d$ として求めた 累積確率の曲線と, $\pi d / 2$ として求めた累積確率の曲

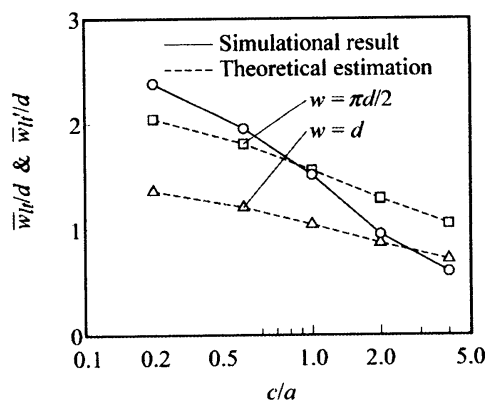

Fig. 10 Difference between average lengths of overlapping part on a fiber end $\bar{w}_{l t}$ and $\bar{w}_{l t}^{\prime}$ estimated by the simple theory and the computer-simulation in several fiber orientation distributions

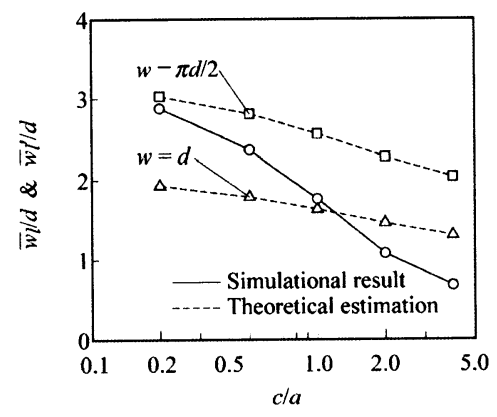

Fig. 11 Difference between average lengths of overlapping part between fiber tips $\bar{w}_{l}$ and $\bar{w}_{l}^{\prime}$ estimated by the simple theory and the computer-simulation in several fiber orientation distributions 
線の間にある。この傾向は, 繊維体積含有率を 0.15 以下にしても同様である.

理論により得られる繊維の先端部分が他の繊維に覆 われる幅の平均值 $\bar{w}_{l t}$ およびシミュレーションにより 得られる繊維の先端部分が他の繊維に覆われる幅の平 均值 $\bar{w}_{l t}^{\prime}$ を求め図 10 に示す。また, 理論により得ら れる繊維端の間が他の繊維に覆われる幅の平均値 $\bar{w}_{l}$ およびシミュレーションにより得られる繊維端の間が 他の繊維に覆われる幅の平均值 $\bar{w}_{l}^{\prime}$ を求め図 11 に示 す. 各平均值は, 繊維方向を表すパラメー夕 c/a の増 加とともに減少する傾向にあるが，理論により求めた 平均値とシミュレーションにより求めた平均值は必ず しも一致しない.

これに関しても詳細な検討が必要であるが，著者は 他の繊維に覆われる幅の平均值は，他の 1 本の繊維が 重なった部分の幅に大きく依存すると考えている。瀻 維方向分布を表すパラメー夕 $c / a$ が 0.2 と試料表面に 対して平行に近い繊維が多い場合には，1本の繊維が 重なった部分の幅の平均値は $\pi d / 2$ に近くなり, 近似 する四角形の幅を $\pi d / 2$ として予測した結果にシミュ レーション結果は近い值となる。これに対して, 繊維 方向分布を表すパラメー夕 $c / a$ が大きくなると, 纎維 の端が重なる確率が高くなって, 1 本の繊維が重なっ た部分の幅の平均值が低下する。このため, 予測した 結果に比べシミュレーション結果は小さい值となった と考えられる。

\section{5. 結言}

本研究においては, 短繊維強化複合材をスライスし, 表面から観察される繊維像に関して, 他の繊維に区切 られたいわゆる可視部分の長さや，他の繊維に覆われ る部分の幅を予測するための理論の検証を行った，空 間中に繊維を数值的に詰め込み，短繊維強化複合材を コンピュータ上で作成した。この複合材を切断して表 面から観察し，他の繊維に区切られたいわゆる可視部 分の長さや, 他の繊維に覆われる部分の幅を求めた. 得られた結果と先に提案した理論結果との比較検討を 行い，提案した理論の適用範囲を検証した。得られた 知見は以下のとおりである.

（1）繊維方向分布が三次元ランダムの場合, 繊維 端と他の繊維に挟まれてできる可視部分の長さの分布 も, 他の 2 本の繊維に挟まれてできる可視部分の長さ の分布も, 重なり部分の幅 $w$ を繊維直径 $d$ で近似し たほうが, $\pi d / 2$ で近似するよりも, シミュレーション 結果に近い結果が得られた。
（2）繊維方向分布をさまざまに変化させても，理 論で得られた可視部分の長さ平均值は，重なり部分 $w$ を繊維直径 $d$ で近似すれば，纎維方向分布が二次元分 布に近い場合を除き，実用上十分な精度で予測できる ことがわかった。

（3）繊維方向分布が三次元ランダムの場合, シミ ュレーションで得られた他の繊維に覆われる部分の幅 の分布は，幅が繊維直径以上の範囲で，重なり部分の 幅 $w$ を繊維直径 $d$ で近似し理論的に求めた分布と, $\pi d / 2$ で近似し理論的に求めた分布の間に入った.

（4）繊維方向分布をさまざまに変化させて，理論 で得られる他の䋊維に覆われる部分の幅の平均値とシ ミュレーションで得られる他の繊維に覆われる部分の 幅の平均值を比較した。両者は同じオーダではある が，現在までの理論では完全には他の纎維に覆われる 部分の幅の平均値を予想するに至っていないといえ た。

本研究の一部は (財) 高橋産業経済研究財団研究助成 によったものであることを付記し謝意を表する。ま た, 本研究の遂行に当たっては八戸工業大学大学院学 生の三津谷郷氏 [現：(株) 荒井製作所］の助力を得た ことを付記し謝意を表する。

\section{文献}

(1) Gusev, A. A., Macromolecules, Vol. 34 (2001), pp. 30813093.

(2) Advani, S. G. and Tucker, C. L. III, Journal of Rheology, Vol. 31 (1987), pp. 751-784.

(3) Chung, D. H. and Kwon, T. H., Korea-Australia Rheology Journal, Vol. 14 (2002), pp. 175-188.

(4) Hille, D. et al., Composites Science and Technology, Vol. 35 (1989), pp. 195-206.

(5) Clarke, A. R. et al., Composites Science and Technol ogy, Vol. 55 (1995), pp. 75-91.

(6) Royer, S. M. and Kinnamon, J. C., Microscopy Research and Technique, Vol. 29 (1994), pp. 381-407.

( 7 ) Eberhardt, C. N. and Clarke, A. R., Journal of Micros. copy, Vol. 2002 (2001), pp. 41-53.

(8) Davidson, N. C. et al., Journal of Microscopy, Vol. 185 (1997), pp. 233-242.

(9) Suzuki, H., Transactions of the Japan Society of Mechanical Engineers, Series A, Vol.73, No.725 (2007), pp. 26-33.

(10) Suzuki, H., Transactions of the Japan Society of Mechanical Engineers, Series A, Vol.66, No.648 (2000), pp. 1468-1476.

(11) Suzuki, H., Transactions of the Japan Society of Mechanical Engineers, Series A, Vol.69, No. 683 (2003), pp. 719-726.

(12) Torquato S., Random Heterogeneous Materials: Microstructure and Macroscopic Properties, (2001), p. 54, Springer-Verlag. 